\title{
SIMULATION OF AUTOMOTIVE STARTER FAULTS
}

\section{SYMULACJA USZKODZEŃ ROZRUSZNIKA SAMOCHODOWEGO}

\author{
Mieczysław Dziubiński' ${ }^{1)}$, Ewa Siemionek ${ }^{1)}$, Mieczysław Plich ${ }^{2)}$, \\ Artur Drozd $^{1)}$, Krzysztof Toborek ${ }^{3)}$ \\ ${ }^{1)}$ Politechnika Lubelska, Wydział Mechaniczny, \\ ${ }^{1)}$ Lublin University of Technology, Faculty of Mechanical Engineering \\ ${ }^{2}$ Politechnika Warszawska, Wydział Transportu \\ ${ }^{2}$ Warsaw University of Technology, Faculty of Transport \\ ${ }^{3)}$ Politechnika Lubelska, Wydział Elektrotechniki i Informatyki \\ ${ }^{3}$ Lublin University of Technology, Faculty of Electrical Engineering and Computer Science

\begin{abstract}
The article presents a new diagnostic method of a motor starter based on the analysis of the starter's power and the Hall effect. Using the Matlab Simulink program the wear and tear impact of the starter sleeves on power characteristics was simulated. For the analysis of the flux propagation and the distribution of magnetic induction for selected states of the wear and tear of the sleeve the QuickField program was used. Within the experimental tests, registration of the distribution of magnetic induction was conducted by the Hall sensor placed in the link slot. The model and the tests made it possible to develop diagnostic patterns within the OBD diagnostics.
\end{abstract}

Keywords: starter faults, reliability, QuickField

Streszczenie: $W$ artykule przedstawiono nowa metode diagnostyki rozrusznika samochodowego na podstawie analizy mocy rozrusznika $i$ zjawiska Halla. Wykorzystujac oprogramowanie Matlab Silmulink zasymulowano wplyw eksploatacyjnego zużcia tulejek rozrusznika na charakterystyki mocy. Do analizy rozplywu strumienia $i$ rozkładu indukcji magnetycznej dla wybranych stanów eksploatacyjnego zużycia tulejki zostat wykorzystany program QuickField. $W$ ramach eksperymentalnych badań przeprowadzono rejestracje rozktadu indukcji magnetycznej za pomoca czujnika Halla umieszczonego w szczelinie przyjarzmowej rozrusznika. Opracowany model oraz przeprowadzane badania umożliwity opracowanie wzorców diagnostycznych w ramach diagnostyki $O B D$.

Stowa kluczowe: uszkodzenia rozrusznika, niezawodność, QuickField 


\section{SIMULATION OF AUTOMOTIVE STARTER FAULTS}

\section{Introduction}

The subject of the article falls within the scope of studies on the diagnosis and reliability of automotive engines together with their accessories, and the impact of their condition on ecology. In the absence of sufficient knowledge of the physical and chemical processes underlying issues of the friction and wear of components, modelling and forecasting of the course wear and tear it is mainly based on empirical research. [1,7-10].

Reliable operation of the starter and preventing its unexpected damage during operation of the vehicle is helped by continuous functional diagnostics. Up to now, the starting circuit has not been under control and it was not possible to determine the border state in which its further exploitation would not be advisable. The starting circuit is the only circuit in the electrical system of the car that is not monitored in the form of the control lights or information in the on-board computer.

In the functional diagnosis electrical quantities are used as diagnostic signals. The solution is to determine the impact of phenomena caused by the wear of consumable parts of the starter and changes in the resistance of the power supply circuit on the waveform characteristics of the boot circuit.

The intensity of the current consumed by the electric automotive starter is a diagnostic signal used in the practice of exploitation (in assessing the tightness of the combustion chamber) and in studies on new methods of diagnosing the device's technical condition. It is generally accepted that the technical condition of the starter at the time of diagnosis corresponds to the starter's actual technical condition. The error of the diagnostic methods used results from assumptions not predicting operational analysis of consumption in the framework of the periodic servicing of vehicle starters. Manufacturers of starters do not provide information on the operational wear. When a starter does not meet its function, it is replaced.

\section{Simulation tests in Matlab Simulink and QuickField programme}

The article develops the model and simulation of the wear and tear of starter sleeves by changing the size of the starter armature slot. The simulation was performed using the QuickField software. The analysis of the impact of the starter sleeves' condition on the device's power curve was conducted in the Matlab Simulink program.

The starter model was developed based on the theory of electrical machines of motor vehicles [2-6].

A block diagram of a Matlab Simulink simulation of damage is shown in Figure 1.

In order to perform the simulation, the following data were entered:

- mechanical and electrical rated power,

- rated voltage,

- the rotational speed of the starter motor at rated power,

- battery capacity,

- resistance of the cables connecting the starter with the battery,

- rated current,

- efficiency, 
- number of rotor slots,

- number of active rods of the rotor winding,

- length and diameter of the rotor packet,

- outer and inner diameter of the body of the starter,

- length of the body, number of pole pairs,

- dimensions of the pole pieces,

- current value of the wrap of the rotor, conductivity and thickness of copper,

- voltage drop across the brushes.

The variable value is the armature slot value. The output values include: electric power and mechanical starter circuit current, voltage at the starter, power drawn by the starter, current wrap of the rotor, magnetic induction in the armature slot, electromagnetic torque of the starter.

The simulations produced the starter power curves for the sleeves' wear and tear corresponding to the armature slot of $0.5 \mathrm{~mm}, 1 \mathrm{~mm}$ and $1.5 \mathrm{~mm}$. Summary of the power characteristics of the R5 starter for selected armature slot values is shown in Figure 2. The solid line indicates a slot of $0.5 \mathrm{~mm}$, the dashed line a slot equal to 1 $\mathrm{mm}$, and the dotted line a slot of $1.5 \mathrm{~mm}$.

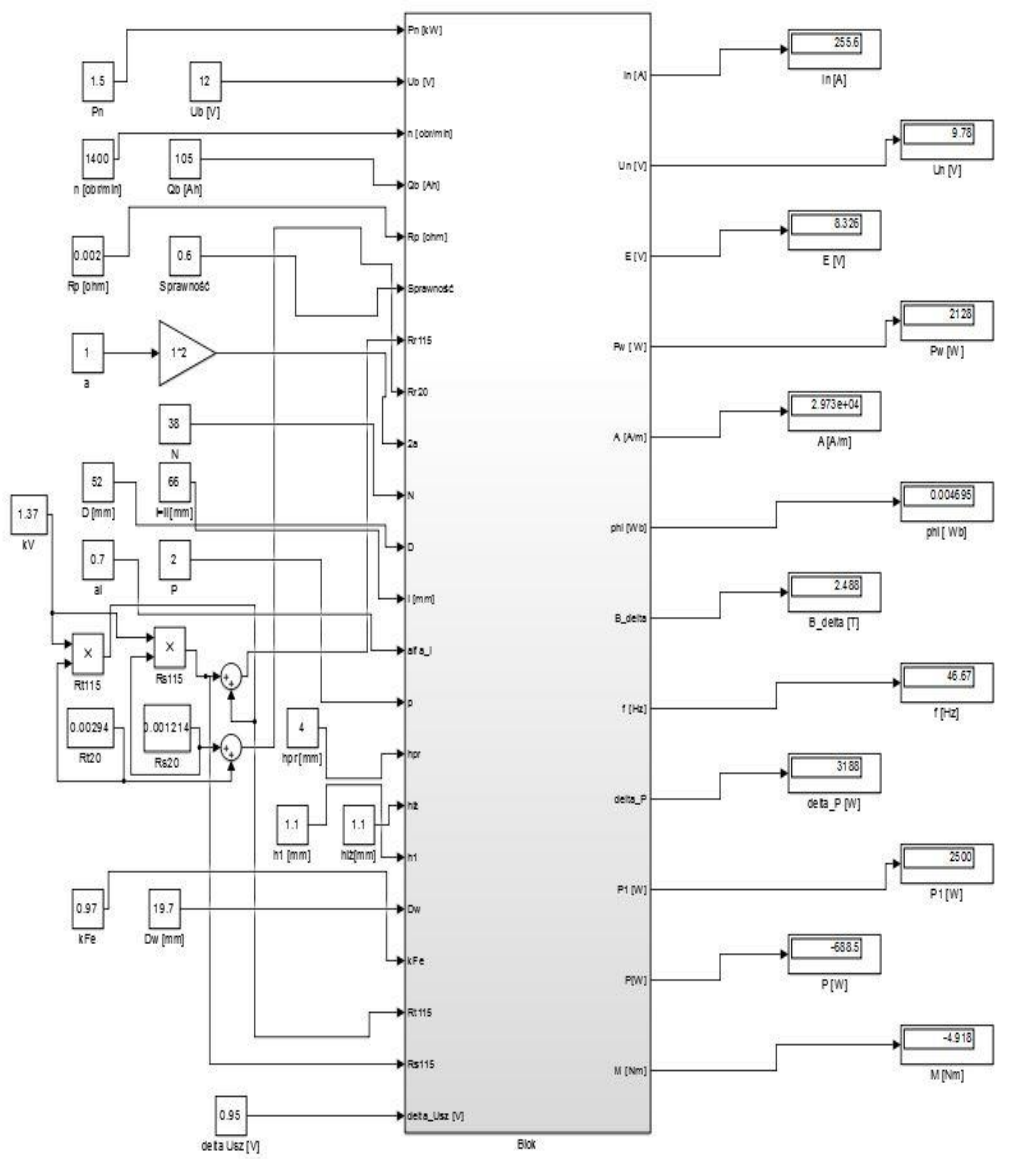

Fig. 1 Matlab Simulink program for R5 starter 


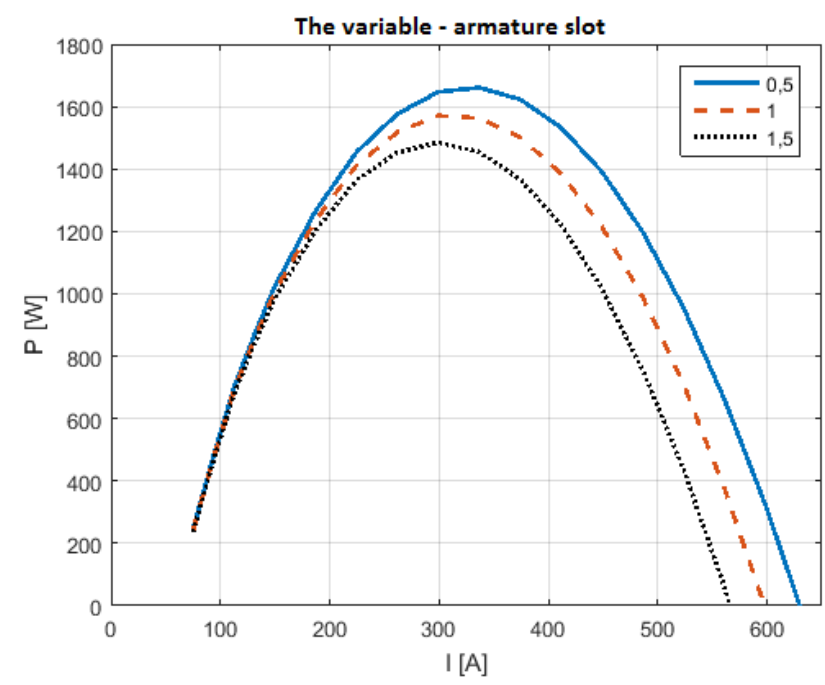

Fig. 2 Characteristics of the R5 starter power for selected armature slot values

The size of the armature slot affects the power developed by the starter and the short-circuit current. For the armature slot of $0.5 \mathrm{~mm}$ the starter has reached the power of $1650 \mathrm{~W}$ and the short-circuit current of $650 \mathrm{~A}$. Increasing the gap to $1 \mathrm{~mm}$ reduced the starter power by $100 \mathrm{~W}$, and the short-circuit current by $50 \mathrm{~A}$. The introduction into the model of an air gap of $1.5 \mathrm{~mm}$ results in reducing the power to $1450 \mathrm{~W}$. At this size of the gap the short-circuit current is $570 \mathrm{~A}$.

For the analysis of the distribution of magnetic flux and of the recorded signals the QuickField computer program was used, allowing the analysis of the flux propagation and the distribution of induction using the finite element method. Calculations of the flux propagation and the distribution of magnetic induction in the QuickField program consist of three stages: preparation of the starter input data, calculations and analysis of results. The program allowed to perform editing by: formulation of a research problem (type of damage in the form of the variable armature slot), introduction of appropriate magnetic materials (magnetisation curve) and mapping the shapes of the starter elements (rotor and stator). Another operation was the introduction of the edges and vertices of the starter model blocks. On the basis of the calculations, the program allowed the visualisation of the propagation of magnetic flux and the distribution of magnetic induction for the operational wear of the starter sleeves.

Apart from the starter dimensions, the QuickField program was fed data on the type of excitation (serial) and the number of starter slots for starter R5 (Fig. 3). The main parameter to illustrate distribution of the flux and induction were the current values in the excitation and rotor windings. By introducing into the program the variable value of the armature slot, the operational wear of the starter sleeves were simulated. Sample grids and distributions of magnetic flux in the R5 starter are shown in Figures 4-7. 
Mieczysław Dziubiński, Ewa Siemionek, Mieczysław Plich, Artur Drozd, Krzysztof Toborek

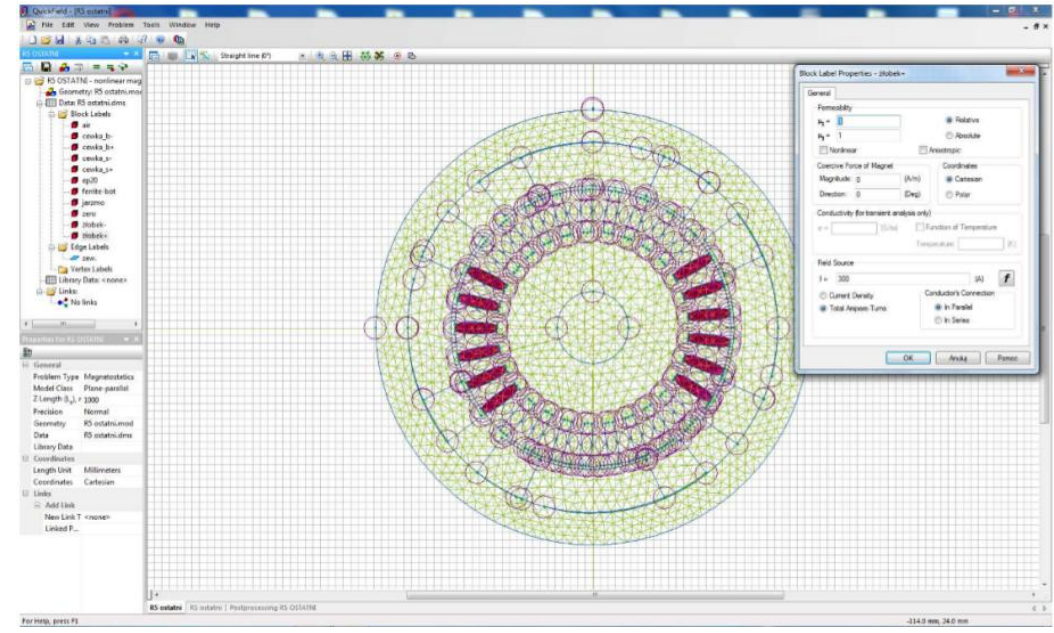

Fig. 3 Entering starter input data in the QuickField program.

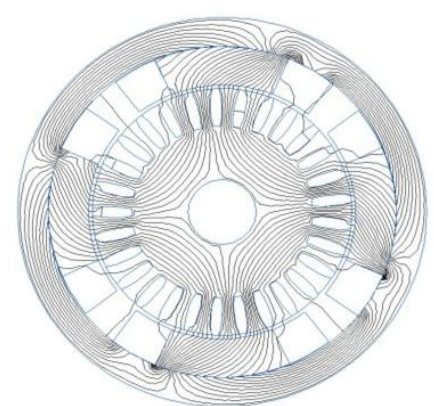

Fig. 4 Distribution of flux for efficient R5 starter

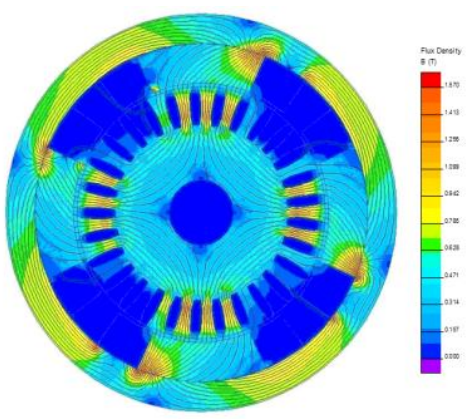

Fig. 6 Distribution of magnetic induction for efficient R5 starter

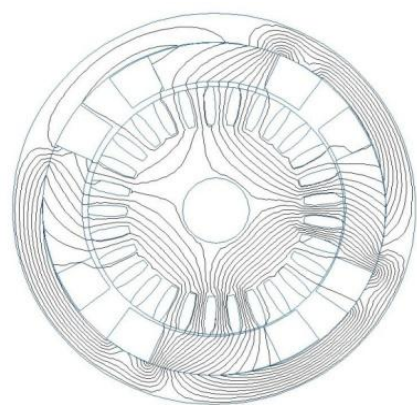

Fig. 5 Distribution of flux for efficient $R 5$ starter with used sleeve

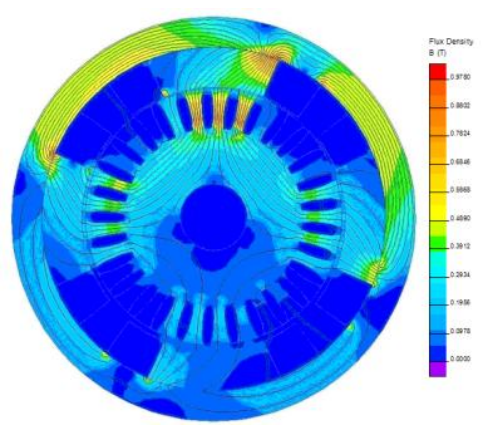

Fig. 7 Distribution of magnetic induction for $R 5$ starter with used sleeve 
Simulation of fault automotive starter

Symulacja uszkodzeń rozrusznika samochodowego

On the basis of the simulation it was found that the greatest values of magnetic induction are in the yoke between the pole pieces and in the link slot. An analysis of flux propagation for an efficient R5 starter (Fig. 4) shows a symmetrical distribution of the stream in the pole shoes and rotor. On the other hand, for a simulated fault in the form of a used sleeve (Fig. 5) the propagation of flux is asymmetrical for each pair of pole pieces. For an efficient starter (Fig. 6) the distribution of magnetic induction is symmetrical, and the largest values are assumed in the yoke, reaching $0.8 \mathrm{~T}$. Distribution of magnetic induction for starter R5 with the used sleeve is asymmetrical (Fig. 7).

\section{Experimental tests}

For verification of the power curves simulated in Matlab Simulink and the armature slots simulated in the QuickField program, experimental tests were conducted on the ELKON SUPER 3 test stand shown in Figure 8. The test stand includes the tested R5 starter, which has been specially prepared by placing the Hall sensor in the link slot. The measurements were made by switching the starter at idle, followed by the process of braking to a stop.

The study was conducted for an effective starter and a starter with worn sleeves. The test stand includes a measurement set: Ad-Link measuring card, power supplies, laptop.

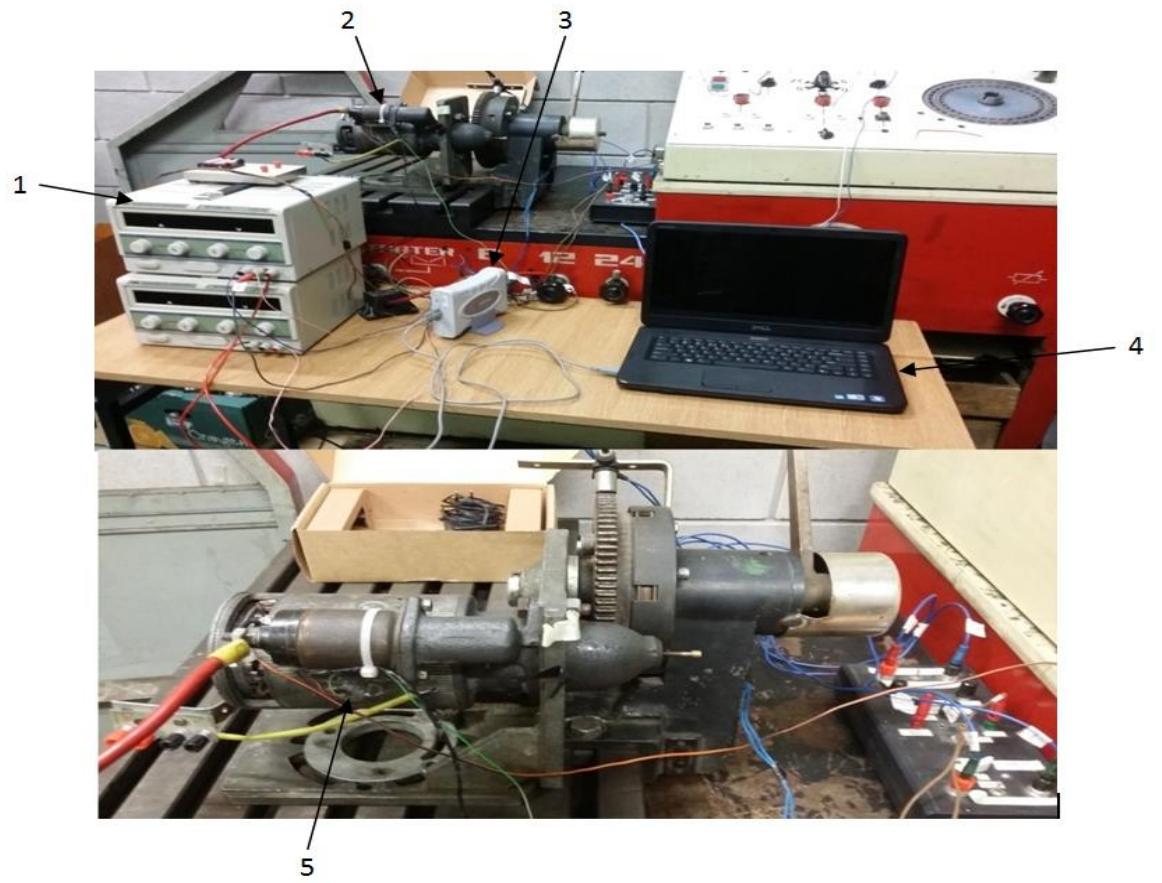

Fig. 8 ELKON SUPER 3 test stand for starter testing;

1 - power supplies; 2 -starter tested; 3 - measuring card; 4 -laptop, 5-Hall sensor placed in the starter 
Mieczysław Dziubiński, Ewa Siemionek, Mieczysław Plich, Artur Drozd, Krzysztof Toborek

Figures 9 and 10 show the recorded waveforms of electrical power for an efficient starter and for a starter with a used sleeve. The power characteristics shown point to the difference of $200 \mathrm{~W}$ between the simulated and recorded maximum power.

Figures 11 and 12 are registered waveforms of magnetic induction in the link slot for an efficient starter and a starter with a used sleeve. From the analysis of the characteristics it can be seen that the maximum value of the induction for an efficient starter was $410 \mathrm{Gs}$, while for a starter with a used sleeve it was $380 \mathrm{Gs}$.

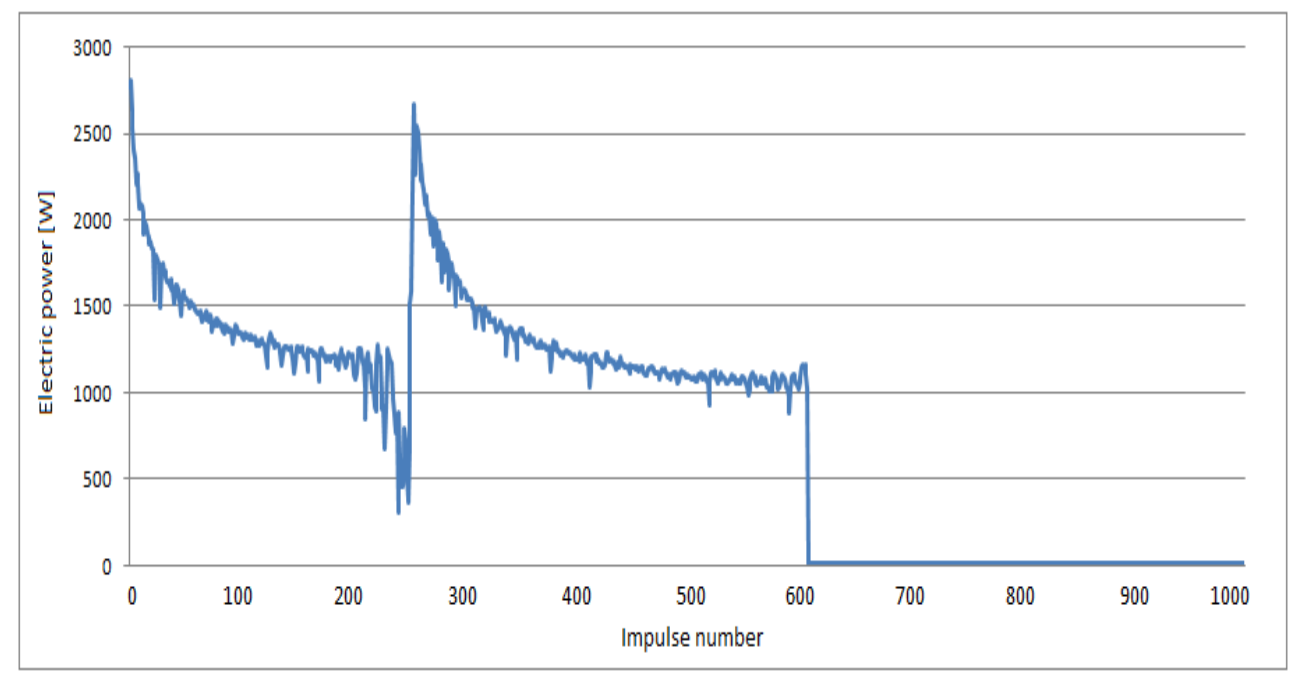

Fig. 9 Characteristics of electric power for the efficient starter

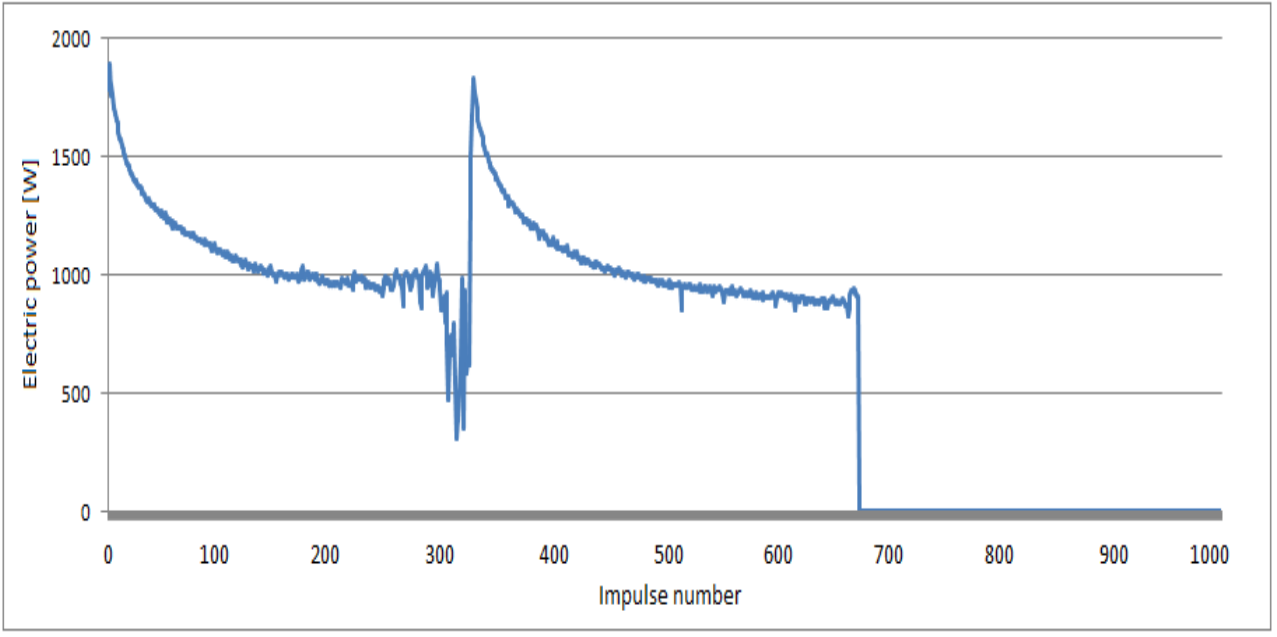

Fig. 10 Characteristics of electric power for the starter with a used sleeve 


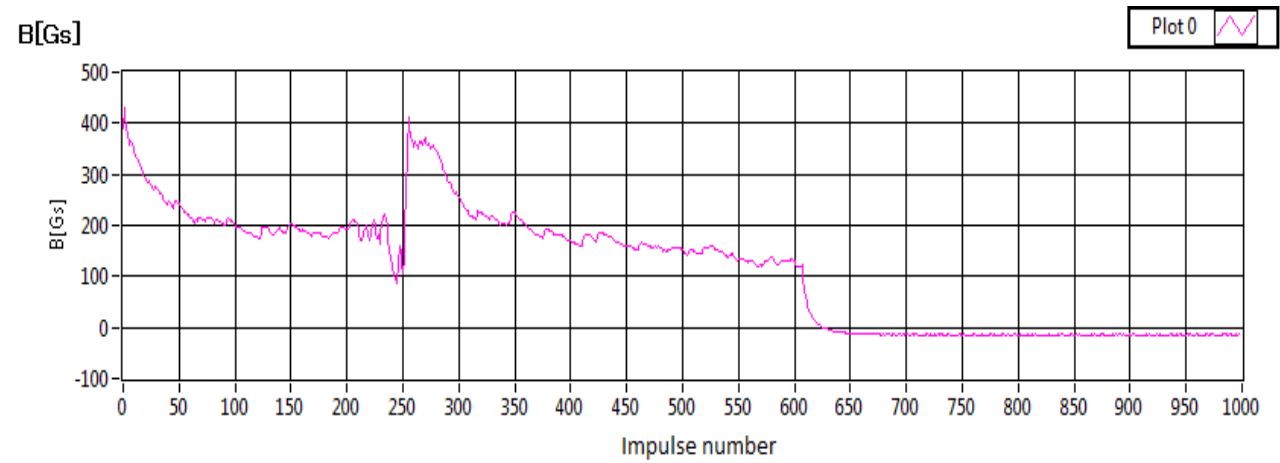

Fig. 11 Characteristics of magnetic induction for the efficient starter

$B[G s]$ \begin{tabular}{|l|}
\hline Plot $0 ~$ \\
\hline
\end{tabular}

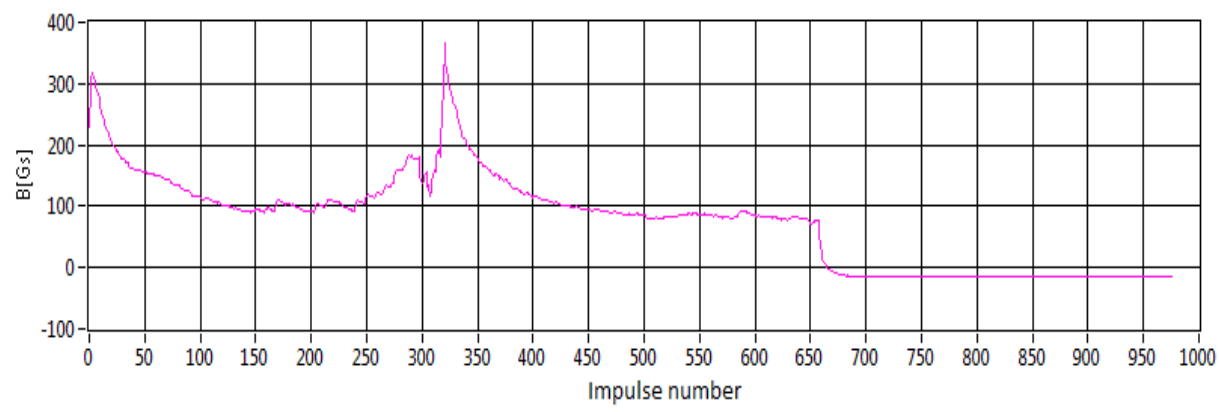

Fig. 12 Characteristics of magnetic induction for the starter with a used sleeve

\section{Summary}

The model developed by the authors in the Matlab Simulink program made it possible to simulate the power characteristics of a starter for operational wear of the starter sleeves. The greatest starter power was reached for the smallest armature slot, which corresponds to anefficient starter. Increase in the size of the slot, resulting from the operational wear of the starter sleeves, lowers the starter's maximum power.

The modelling of the armature slot asymmetry carried out in the present work, related to the operational wear of the sleeves, allowed the analysis of the flux propagation and the distribution of magnetic induction. The analysis shows an uneven distribution of induction and propagation of the flux for a starter with an operationally worn sleeve. The simulation extends the current state of knowledge and allows to assess the use of measurements of magnetic induction for new diagnostics-reliability applications.

The experimental verification tests carried out confirmed the compliance of the obtained power characteristics with modelling in the Matlab Simulink program. 
The registered characteristics of magnetic induction for an efficient starter and a starter with a used sleeve allow to prepare diagnostic patterns within the OBD (On-Board-Diagnosis) program.

The simulation results confirmed the effect of the starter's armature slot on the characteristics of power and distribution of induction.

\section{References}

[1] Cioska A.: Rozkłady przestrzenne wartości maksymalnych indukcji magnetycznej w szczelinie powietrznej maszyn prądu przemiennego, Przegląd Elektrotechniczny, ISSN 0033-2097, r. 83, nr 3, 2007, s. 15-18.

[2] Dudzikowski I., Ciurys M.: Komutatorowe i bezszczotkowe maszyny elektryczne wzbudzane magnesami trwałymi, Postępy napędu elektrycznego i energoelektryki, Oficyna Wydawnicza Politechniki Wrocławskiej, ISBN 978-837493-653-8, t. 20, Wrocław 2011.

[3] Dziubiński M., Drozd A., Adamiec M., Siemionek E.: Simulation tests of the starting system, Poznań University of Technology Academic Journals. Electrical Engineering, Poznań Univeristy of Technology, ISSN 1897-0737, nr 88, Poznań 2016, s. 89-100.

[4] Dziubiński M., Krasowski E., Plizga K.: Metody rozpoznawania uszkodzeń rozruszników samochodowych, „33 Zimowa Szkoła Niezawodności. Metody badań przyczyn i skutków uszkodzeń", Sekcja Podstaw Eksploatacji Komitetu Budowy Maszyn Polskiej Akademii Nauk, Szczyrk 2005, s. 106-117.

[5] Dziubiński M., Ocioszyński J., Walusiak S.: Elektrotechnika i elektronika samochodowa. Wydawnictwa Uczelniane Politechniki Lubelskiej, Lublin 1999.

[6] Dziubiński M., Plich M., Drozd A.: Modelling and simulation characteristics of starting system, Journal of KONBIN-Safety and Reliability System, ISSN 18958281, nr 1 (37), 2016, s. 277-386.

[7] Frisk E., Krysander M., Nyberg M., Aslund J.: A toolbox for design of diagnosis systems, 6th IFAC Symposium on Fault Detection, „Supervision and Safety of Technical Processes", International Federation of Automatic Control, 2006.

[8] Füvesi $V$., Kovács $E$., Blága $C$.: Measurement and identification of a starter motor system, Proceedings of the 2nd international conference on recent chievements in mechatronics,automation, computer science and robotics, Macro 2010, Cientiascientia Publishing House, Cluj-Napoca 2010, s. 129-134. 
Simulation of fault automotive starter

Symulacja uszkodzeń rozrusznika samochodowego

[9] Pasko J.: Ocena niezawodności podsystemu wytwórczego systemu elektroenergetycznego, Politechnika Warszawska. Prace Naukowe. Elektryka, Oficyna Wydawnicza Politechniki Warszawskiej, ISSN 0137-2319, z. 120, Warszawa 2002.

[10] Sęk A., Polakowski K.: Analiza pola magnetycznego w rozruszniku samochodowym z magnesami trwałymi i przekładnią planetarną, Przegląd Elektrotechniczny, $\mathrm{nr}$ 7-8, 2004, s. 702-705.

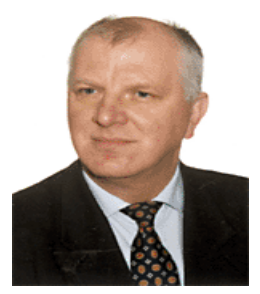

Mieczyslaw Dziubiński, PhD. Eng. works at the Mechanical Department of the Faculty of Motor Vehicles at the Lublin University of Technology. In his scientific work he deals with the diagnostics, electrotechnology and electronics of cars.

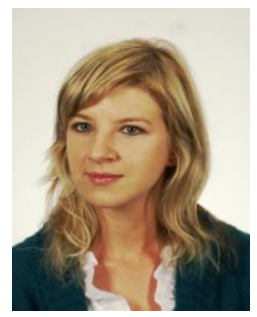

Ewa Siemionek M.Sc. Eng. works at the Mechanical Department of the Faculty of Motor Vehicles at the Lublin University of Technology. She deals with the study of energy consumption in electric vehicles.

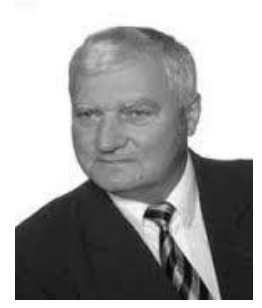

Mieczystaw Plich PhD. Eng. works at the Department of Informatics and Mechatronics Systems in Transport, Faculty of Transport, at the Warsaw University of Technology. In his scientific work he deals with the electric equipment of motor vehicles.

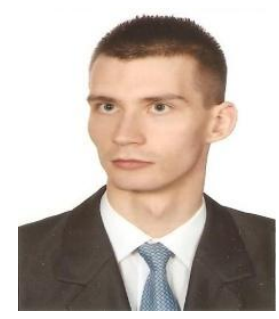

Artur Drozd M.Sc. Eng. graduated from the Transport Faculty at the Lublin University of Technology. He is currently a PhD student, doing research on the starting systems of motor vehicles.

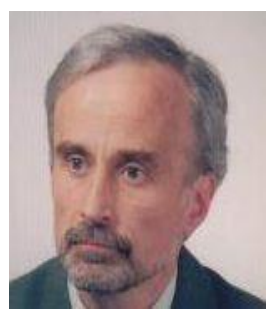

Krzysztof Toborek M.Sc. Eng. works at the Department of Automation and Metrology at the Faculty of Electrical Engineering and Computer Science of the Lublin University of Technology. His scientific interests focus on programming with the LabVIEW software. 


\section{SYMULACJA USZKODZEŃ ROZRUSZNIKA SAMOCHODOWEGO}

\section{Wstęp}

Tematyka artykułu wpisuje się w zakres prowadzonych w kraju badań dotyczących diagnostyki i niezawodności silników samochodowych wraz $\mathrm{z}$ jego osprzętem i wpływu ich stanu na ekologię. Z powodu braku dostatecznej znajomości procesów fizyko-chemicznych leżących u podstaw zagadnień tarcia i zużywania się elementów, modelowanie i prognozowanie przebiegu zużycia eksploatacyjnego opiera się głównie na badaniach empirycznych[1,7-10].

Niezawodnej pracy rozrusznika i zapobieganiu jego niespodziewanym uszkodzeniom podczas eksploatacji pojazdu sprzyja prowadzona w sposób ciągły diagnostyka funkcjonalna. Dotychczas nie był dozorowany obwód rozruchowy i nie było możliwe wyznaczenie stanu granicznego, w którym dalsze jego eksploatowanie nie jest wskazane. Obwód rozruchu jest jedynym obwodem w instalacji elektrycznej samochodu, który nie jest monitorowany w postaci lampki kontrolnej lub informacji w komputerze pokładowym.

$\mathrm{W}$ diagnostyce funkcjonalnej wielkości elektryczne wykorzystywane są jako sygnały diagnostyczne. Rozwiązanie problemu polega na określeniu wpływu zjawisk wywołanych zużywaniem eksploatacyjnym elementów rozrusznika oraz zmianami rezystancji $\mathrm{w}$ obwodzie zasilania na przebiegi charakterystyk obwodu rozruchowego.

Natężenie prądu pobieranego przez elektryczny rozrusznik samochodowy stanowi sygnał diagnostyczny, wykorzystywany w praktyce eksploatacyjnej (przy ocenie szczelności komory spalania) oraz badaniach diagnostycznych nad nowymi metodami diagnozowania stanu technicznego. Powszechnie przyjmuję się, że stan techniczny rozrusznika w chwili diagnozy odpowiada stanowi technicznemu rozrusznika. Błąd stosowanych metod diagnostycznych wynikający z założeń nie przewidujących analizy eksploatacyjnego zużycia w ramach okresowych obsług eksploatacyjnych rozruszników w pojazdach. Producenci rozruszników nie udostępniają informacji na ten temat eksploatacyjnego zużycia. Rozrusznik podlega wymianie, gdy nie spełnia swojej funkcji.

\section{Badania symulacyjne w programie Matlab Simulink i QuickField}

W ramach artykułu opracowano model i przeprowadzono symulację eksploatacyjnego zużycia tulejek rozrusznika poprzez zmianę wielkości szczeliny przytwornikowej rozrusznika. Symulację przeprowadzono z wykorzystaniem oprogramowania QuickField. Analizę wpływu eksploatacyjnego zużycia tulejek rozrusznika na charakterystyki mocy rozrusznika przeprowadzono w programie Matlab Simulink. Model rozrusznika opracowano na podstawie teorii maszyn elektrycznych pojazdów samochodowych [2-6].

Schemat blokowy programu Matlab Simulink dla symulacji uszkodzenia przedstawiono na rys. 1. W celu przeprowadzenia symulacji wprowadzono następujące dane: moc znamionowa mechaniczna i elektryczna, napięcie znamionowe, prędkość obrotowa silnika rozrusznika przy mocy znamionowej, pojemność akumulatora, rezystancja przewodów łączących rozrusznik 
Simulation of fault automotive starter

Symulacja uszkodzeń rozrusznika samochodowego

z akumulatorem, prąd znamionowy, sprawność, liczba żłobków wirnika, liczba czynnych prętów uzwojenia wirnika, średnica i długość pakietu wirnika, średnica zewnętrzna i wewnętrzna korpusu rozrusznika, długość korpusu, liczba par biegunów, wymiary nabiegunników, wartość okładu prądowego wirnika, przewodność i gęstość miedzi oraz spadek napięcia pod szczotkami.

Wielkością zmienną jest wartość szczeliny przytwornikowej.

Do wielkości wyjściowych należą: moc elektryczna i mechaniczna, prąd zwarcia rozrusznika, napięcie na rozruszniku, moc pobrana przez rozrusznik, okład prądowy wirnika, indukcja magnetyczna w szczelinie przytwornikowej, moment elektromagnetyczny rozrusznika.

Z przeprowadzonych symulacji otrzymano charakterystyki mocy rozrusznika dla zużycia eksploatacyjnego tulejek odpowiadającego szczelinie przytwornikowej równej: $0,5 \mathrm{~mm}, 1 \mathrm{~mm}$ oraz $1,5 \mathrm{~mm}$. Zestawienie charakterystyk moc rozrusznika R5 dla wybranych wartości szczeliny przytwornikowej przedstawia rysunek 2 . Linią ciągłą oznaczono szczelinę równą $0,5 \mathrm{~mm}$, linią kreskową szczelinę równą $1 \mathrm{~mm}$, zaś linią punktową szczelinę równą $1,5 \mathrm{~mm}$.

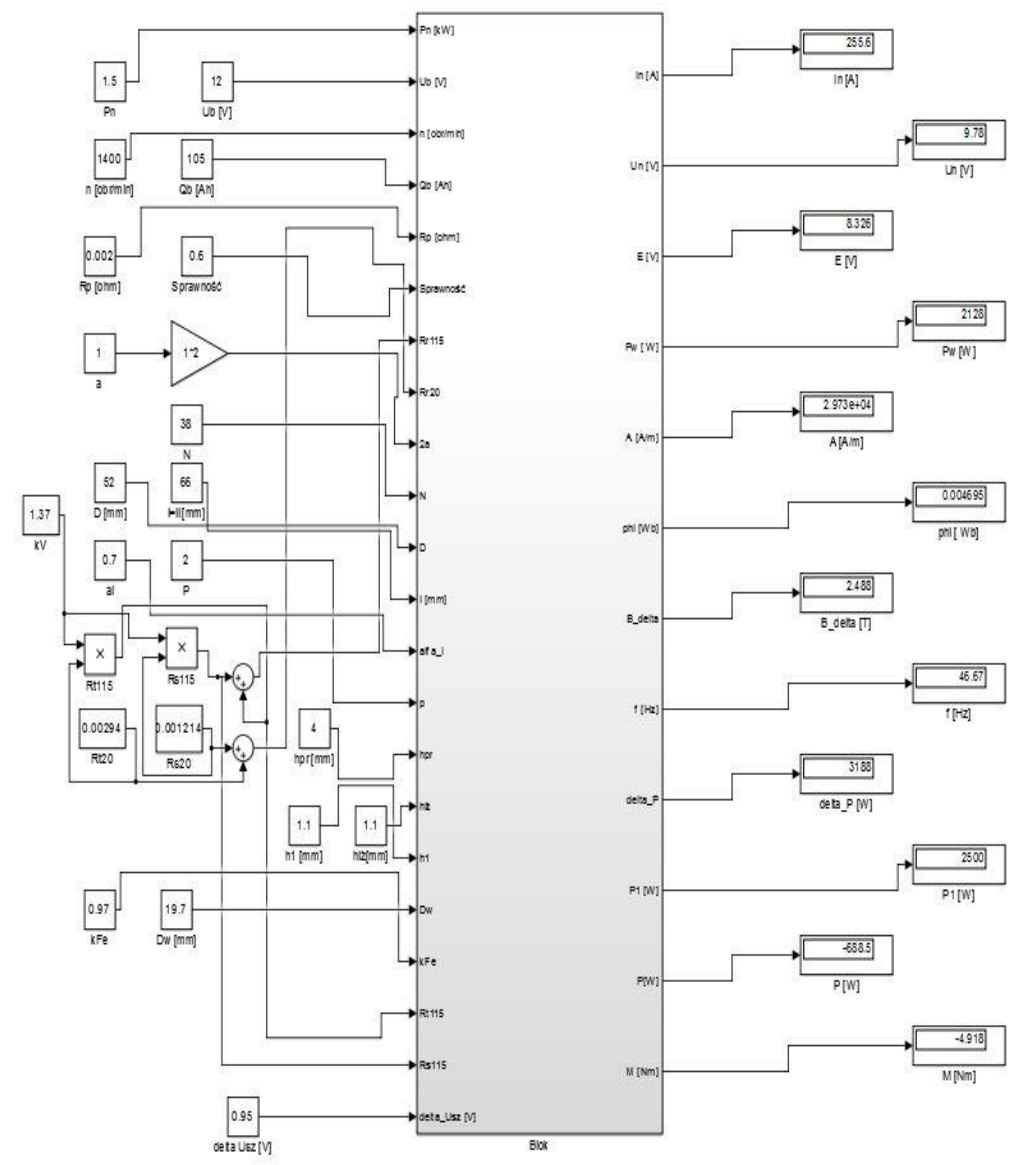

Rys. 1 Program Matlab Simulink dla rozrusznika R5 


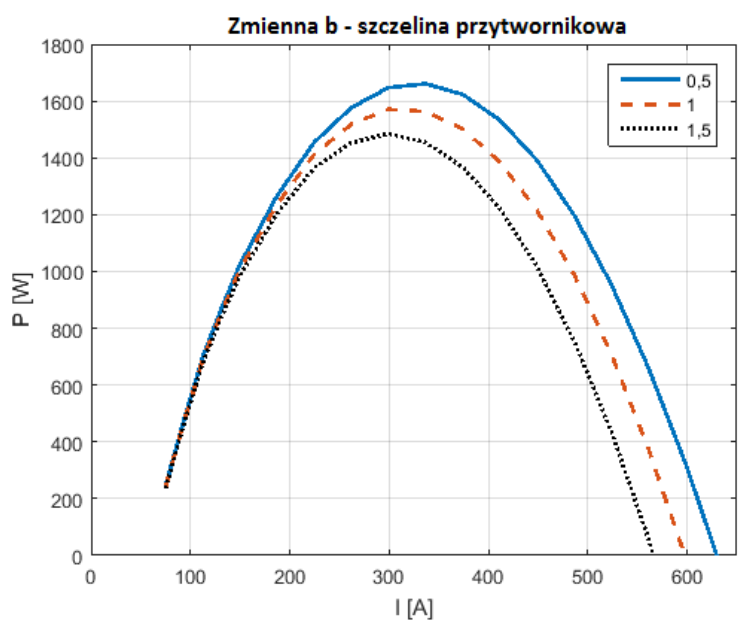

Rys. 2 Charakterystyka mocy rozrusznika $R 5$

dla wybranych wartości szczeliny przytwornikowej

Wielkość szczeliny przytwornikowej wpływa na moc rozwijaną przez rozrusznik oraz prąd zwarcia. Przy szczelinie przytwornikowej równej $0,5 \mathrm{~mm}$ rozrusznik osiągnął moc $1650 \mathrm{~W}$ i prąd zwarcia $650 \mathrm{~A}$, zwiększenie szczeliny do $1 \mathrm{~mm}$ spowodowało obniżenie mocy rozrusznika o $100 \mathrm{~W}$, a prądu zwarcia o $50 \mathrm{~A}$. Wprowadzenie do modelu $1,5 \mathrm{~mm}$ szczeliny powietrznej skutkuje spadkiem mocy do $1450 \mathrm{~W}$. Przy tej wielkości szczeliny prąd zwarcia wynosi $570 \mathrm{~A}$.

Do analizy rozkładu pola magnetycznego oraz zarejestrowanych sygnałów wykorzystano program komputerowy Quick Field umożliwiający przeprowadzenie analizy rozpływu strumienia i rozkładu indukcji przy wykorzystaniu metody elementów skończonych. Obliczenia rozpływu strumienia i rozkładu indukcji magnetycznej w programie Quick Field składają się z trzech etapów: przygotowania danych wejściowych rozrusznika, obliczeń i analizy wyników. Program pozwolił na przeprowadzenie edycji poprzez: sformułowanie problemu badawczego (rodzaju uszkodzenia w postaci zmiennej szczeliny przytwornikowej), wprowadzeniu właściwych materiałów magnetycznych (krzywa magnesowania) oraz odwzorowaniu kształtów elementów rozrusznika (wirnika i stojana). Ponadto wprowadzono krawędzie, wierzchołki bloków modelu rozrusznika. Na podstawie obliczeń program umożliwił wizualizację rozpływu strumienia magnetycznego oraz rozkładu indukcji magnetycznej dla eksploatacyjnego zużycia tulejek rozrusznika.

Do programu QuickField poza wymiarami rozrusznika wprowadzono dane dotyczące rodzaju wzbudzenia (szeregowe) oraz ilości żłobków rozrusznika dla rozrusznika R5 (rys. 3). Podstawowym parametrem dla zilustrowania rozkładu strumienia oraz rozkładu indukcji były wartości prądu w uzwojeniu wzbudzenia oraz $\mathrm{w}$ uzwojeniach wirnika. Wprowadzając do programu zmienną wartość szczeliny przytwornikowej symulowano eksploatacyjne zużycie tulejek rozrusznika. Przykładowe siatki i rozkłady strumienia magnetycznego w rozruszniku R5 przedstawiono na rysunkach 4-7. 
Simulation of fault automotive starter

Symulacja uszkodzeń rozrusznika samochodowego

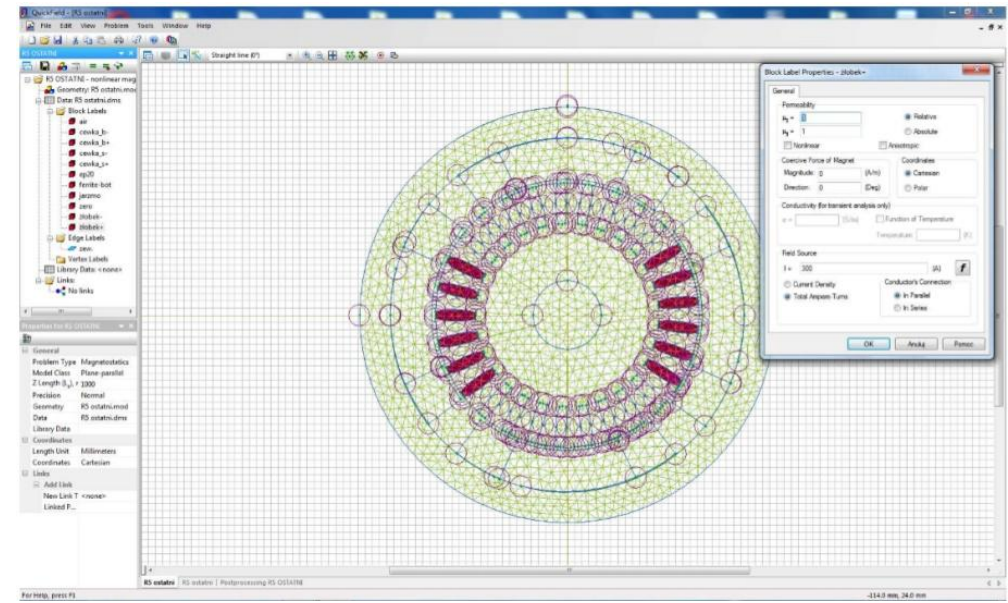

Rys. 3 Wprowadzanie danych wejściowych rozrusznika w programie QuickField

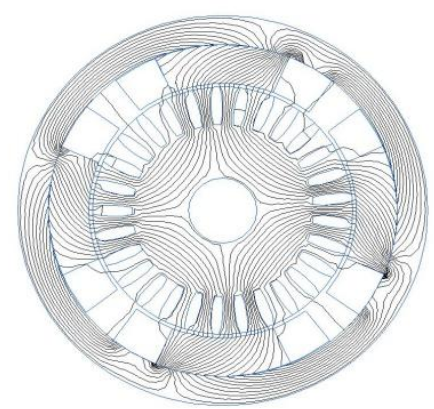

Rys. 4 Rozplyw strumienia magnetycznego dla rozrusznika $R 5$ sprawnego

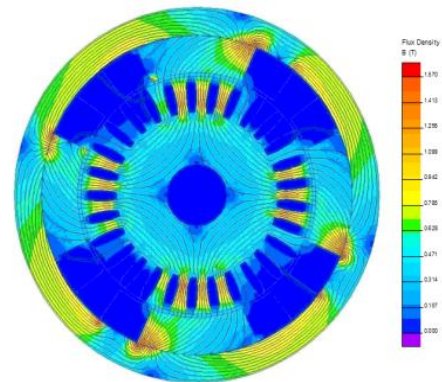

Rys. 6 Rozklad indukcji magnetycznej dla rozrusznika $R 5$ sprawnego

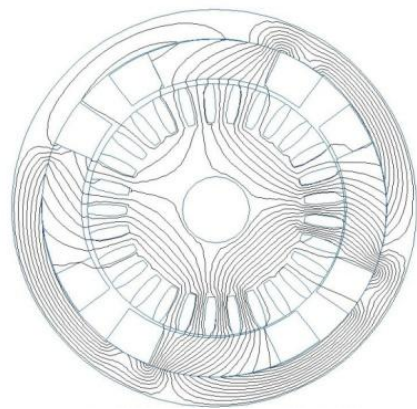

Rys. 5 Rozplyw strumienia magnetycznego dla rozrusznika $R 5$ z zużytą tulejka

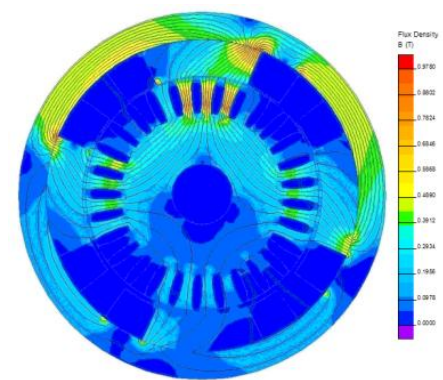

Rys. 7 Rozktad indukcji magnetycznej dla rozrusznika $R 5$ z zużyta tulejka

$\mathrm{Na}$ podstawie przeprowadzonej symulacji stwierdzono, że największe wartości indukcji magnetycznej występuja $\mathrm{w}$ jarzmie między nabiegunnikami oraz szczelinie przyjarzmowej. Z analizy rozpływu strumienia dla rozrusznika R5 sprawnego (rys.4) wynika symetryczny rozkład strumienia w nabiegunnikach oraz w wirniku. 
Mieczysław Dziubiński, Ewa Siemionek, Mieczysław Plich, Artur Drozd, Krzysztof Toborek

Natomiast dla zasymulowanego uszkodzenia w postaci zużycia tulejki (rys.5) rozpływ strumienia jest niesymetryczny dla poszczególnych par nabiegunników. Dla sprawnego rozrusznika (rys. 6) rozkład indukcji magnetycznej jest symetryczny, a największe wartości przyjmuje w jarzmie osiągając $0,8 \mathrm{~T}$. Rozkład indukcji magnetycznej dla rozrusznika R5 z zużytą tulejką jest niesymetryczny (rys.7).

\section{Eksperymentalne badania}

Dla weryfikacji zasymulowanych w programie Matlab Simulink charakterystyk mocy oraz zasymulowanych szczelin przytwornikowych w programie Quick Fild przeprowadzono eksperymentalne badania na stanowisku ELKON-SUPER 3 przedstawionym na rysunku 8 . W skład stanowiska wchodzi badany rozrusznik R5, który został specjalnie przygotowany, poprzez umieszczenie $\mathrm{w}$ szczelinie przyjarzmowej czujnika hallotronowego. Pomiary wykonano włączając rozrusznik na biegu jałowym, a następnie przeprowadzono proces hamowania, aż do zatrzymania.

Badania przeprowadzono dla rozrusznika sprawnego oraz rozrusznika z zużytymi tulejkami. W skład stanowiska wchodzi zestaw pomiarowy: karta pomiarowa Ad-Link, zasilacze, laptop.

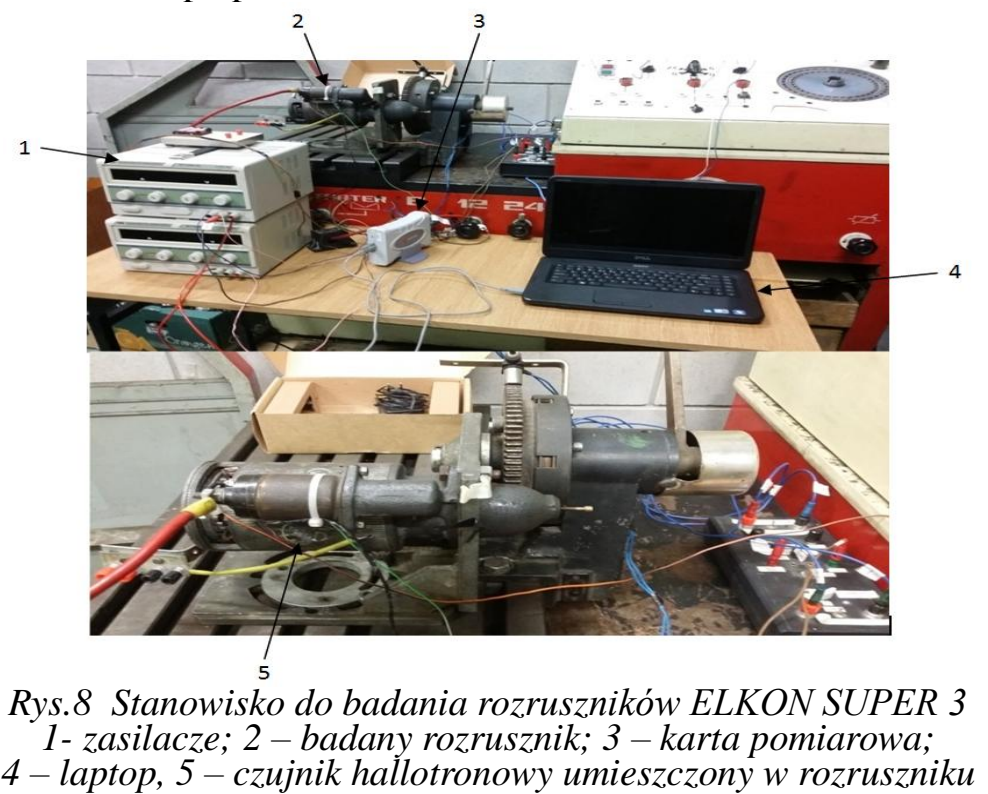

$\mathrm{Na}$ rys. 9 i 10 przedstawiono zarejestrowane przebiegi mocy elektrycznej dla rozrusznika sprawnego oraz dla rozrusznika z zużytą tulejką. Z przedstawionych charakterystyk mocy wynika różnica $200 \mathrm{~W}$ między maksymalną mocą zasymulowaną a zarejestrowaną.

Na rys. 11 i 12 przedstawiono zarejestrowane przebiegi indukcji magnetycznej w szczelinie przyjarzmowej dla rozrusznika sprawnego oraz rozrusznika z zużytą tulejką. $Z$ analizy charakterystyk wynika, że maksymalna wartość indukcji dla rozrusznika sprawnego wynosiła $410 \mathrm{Gs}$, natomiast dla rozrusznika z zużytą tulejką maksymalną wartość indukcji wynosi 380 Gs. 
Simulation of fault automotive starter

Symulacja uszkodzeń rozrusznika samochodowego

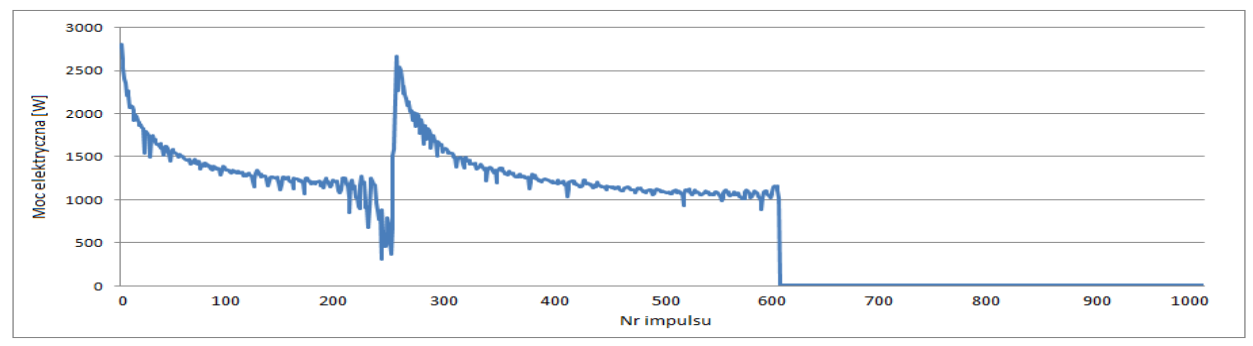

Rys. 9 Charakterystyka mocy elektrycznej dla rozrusznika sprawnego

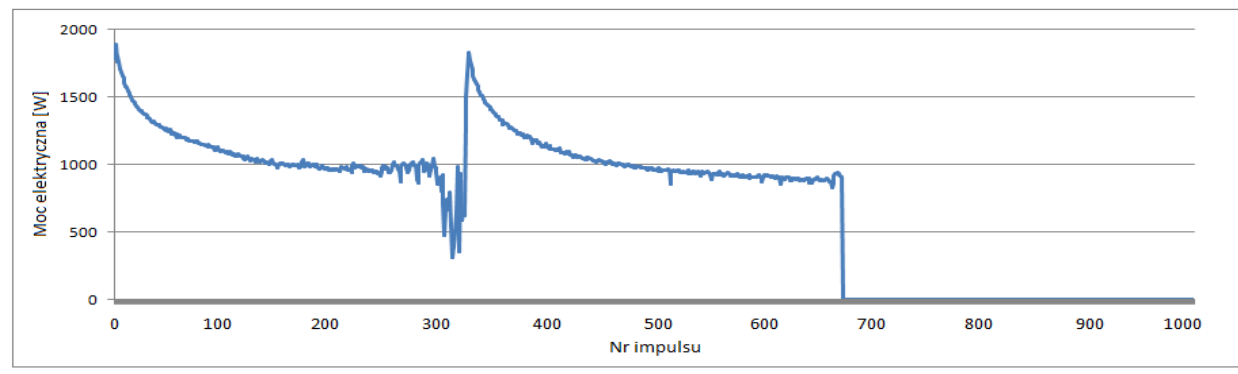

Rys. 10 Charakterystyka mocy elektrycznej dla rozrusznika z zużyta tulejka

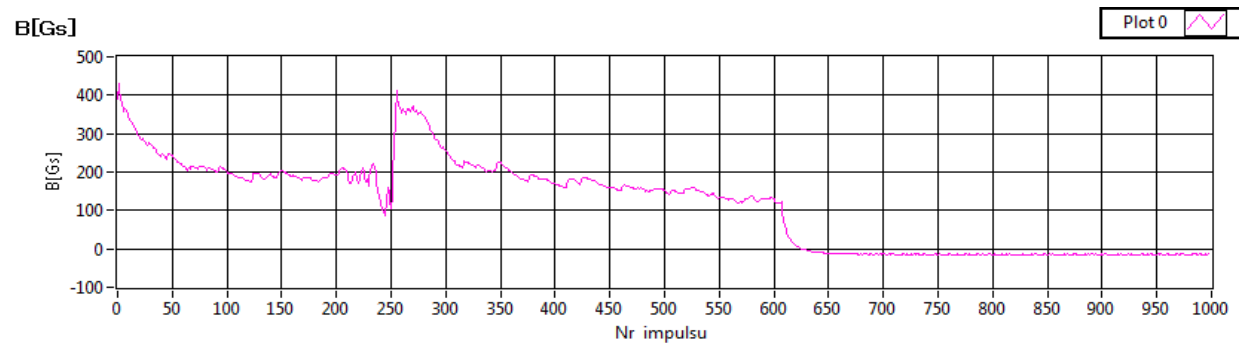

Rys. 11 Charakterystyka indukcji magnetycznej dla rozrusznika sprawnego

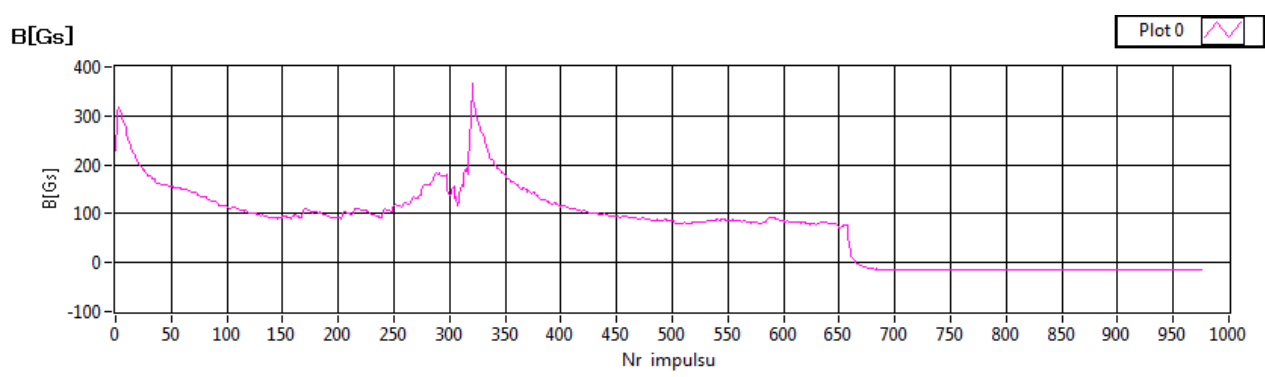

Rys. 12 Charakterystyka indukcji magnetycznej dla rozrusznika z zużyta tulejka

\section{Podsumowanie}

Opracowany przez autorów model w programie Matlab Simulink umożliwił zasymulowanie charakterystyk mocy rozrusznika dla eksploatacyjnego zużycia tulejek rozrusznika. Największą moc rozrusznika osiągnięto dla najmniejszej szczeliny przytwornikowej, która odpowiada sprawnemu rozrusznikowi. 
Mieczysław Dziubiński, Ewa Siemionek, Mieczysław Plich, Artur Drozd, Krzysztof Toborek

Zwiększanie szczeliny związane z eksploatacyjnym zużyciem tulejek rozrusznika powoduje obniżenie mocy maksymalnej rozrusznika.

Przeprowadzone $\mathrm{w}$ pracy modelowanie asymetrii szczeliny przytwornikowej związanej z eksploatacyjnym zużyciem tulejek umożliwiło analizę rozpływu strumienia oraz rozkładu indukcji magnetycznej. $\mathrm{Z}$ analizy wynika nierównomierny rozkład indukcji oraz rozpływ strumienia dla rozrusznika z eksploatacyjnie zużytą tulejką. Symulacja poszerza dotychczasowy stan wiedzy i pozwala przeprowadzić ocenę wykorzystania pomiarów indukcji magnetycznej do nowych zastosowań diagnostyczno-niezawodnościowych

Przeprowadzone eksperymentalne badania weryfikacyjne potwierdziły zgodność otrzymanych charakterystyk mocy z modelowania w programie Matlab Simulink.

Zarejestrowane charakterystyki indukcji magnetycznej dla rozrusznika sprawnego oraz rozrusznika z zużytą tulejką pozwalają opracować wzorce diagnostyczne w ramach programu OBD (On-Board-Diagnosis).

Wyniki symulacji potwierdziły wpływ wartości szczeliny przytwornikowej rozrusznika na charakterystyki mocy i rozkład indukcji.

\section{Literatura}

[1] Cioska A.: Rozkłady przestrzenne wartości maksymalnych indukcji magnetycznej w szczelinie powietrznej maszyn prądu przemiennego, Przegląd Elektrotechniczny, ISSN 0033-2097, r. 83, nr 3, 2007, s. 15-18.

[2] Dudzikowski I., Ciurys M.: Komutatorowe i bezszczotkowe maszyny elektryczne wzbudzane magnesami trwałymi, Postępy napędu elektrycznego i energoelektryki, Oficyna Wydawnicza Politechniki Wrocławskiej, ISBN 978-837493-653-8, t. 20, Wrocław 2011.

[3] Dziubiński M., Drozd A., Adamiec M., Siemionek E.: Simulation tests of the starting system, Poznań University of Technology Academic Journals. Electrical Engineering, Poznań Univeristy of Technology, ISSN 1897-0737, nr 88, Poznań 2016, s. 89-100.

[4] Dziubiński M., Krasowski E., Plizga K.: Metody rozpoznawania uszkodzeń rozruszników samochodowych, „33 Zimowa Szkoła Niezawodności. Metody badań przyczyn i skutków uszkodzeń”, Sekcja Podstaw Eksploatacji Komitetu Budowy Maszyn Polskiej Akademii Nauk, Szczyrk 2005, s. 106-117.

[5] Dziubiński M., Ocioszyński J., Walusiak S.: Elektrotechnika i elektronika samochodowa. Wydawnictwa Uczelniane Politechniki Lubelskiej, Lublin 1999.

[6] Dziubiński M., Plich M., Drozd A.: Modelling and simulation characteristics of starting system, Journal of KONBIN-Safety and Reliability System, ISSN 18958281, nr 1 (37), 2016, s. 277-386.

[7] Frisk E., Krysander M., Nyberg M., Aslund J.: A toolbox for design of diagnosis systems, 6th IFAC Symposium on Fault Detection, ..Supervision and Safety of Technical Processes", International Federation of Automatic Control, 2006.

[8] Fuvesi V., Kovacs E., Blaga C.: Measurement and identification of a starter motor system, „Proceedings of the 2 nd international conference on recent chievements in mechatronics,automation, computer science and robotics, Macro 2010", Cientiascientia Publishing House, Cluj-Napoca 2010, s. 129-134. 
Simulation of fault automotive starter

Symulacja uszkodzeń rozrusznika samochodowego

[9] Pasko J.: Ocena niezawodności podsystemu wytwórczego systemu elektroenergetycznego, Politechnika Warszawska. Prace Naukowe. Elektryka, Oficyna Wydawnicza Politechniki Warszawskiej, ISSN 0137-2319, z. 120, Warszawa 2002.

[10] Sęk A., Polakowski K.: Analiza pola magnetycznego w rozruszniku samochodowym z magnesami trwałymi i przekładnią planetarną, Przegląd Elektrotechniczny, nr 7-8, 2004, s. 702-705.

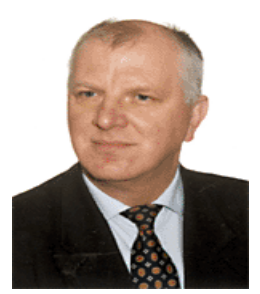

Dr inz. Mieczyslaw Dziubiński pracuje w Katedrze Pojazdów Samochodowych na Wydziale Mechanicznym Politechniki Lubelskiej. Zajmuje się diagnostyka, elektrotechnika i elektronika samochodowa.

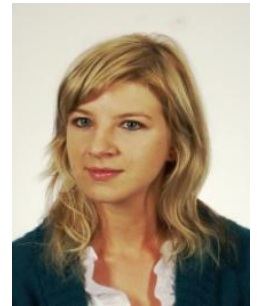

Mgr inj. Ewa Siemionek pracuje $w$ Katedrze Pojazdów Samochodowych na Wydziale Mechanicznym Politechniki Lubelskiej. Zajmuje się badaniami energochłonności pojazdów z napędem elektrycznym.

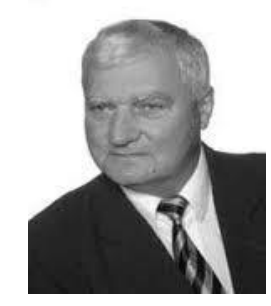

Dr inz. Mieczystaw Plich pracuje w Zakladzie Systemów Informatycznych i Mechatronicznych w Transporcie na Wydziale Transportu Politechniki Warszawskiej. W swojej pracy naukowej zajmuje się głównie tematyka zwiazana $z$ elektrycznym wyposażeniem pojazdów samochodowych.

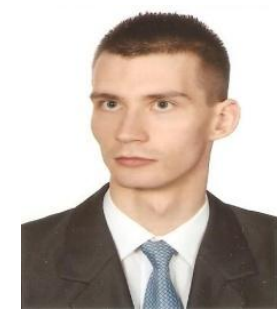

Mgr inz. Artur Drozd ukończyt kierunek Transport na Politechnice Lubelskiej. Obecnie kontynuuje nauke na studiach doktoranckich. Prowadzi badania zwiazane $z$ uktadem rozruchowym pojazdów samochodowych.

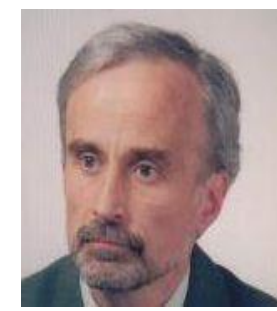

Mgr inz. Krzysztof Toborek pracuje w Katedrze Automatyki $i$ Metrologii na Wydziale Elektrotechniki $i$ Informatyki Politechniki Lubelskiej. $W$ centrum jego zainteresowań naukowych jest programowanie z wykorzystaniem środowiska LabVIEW. 